\title{
TROŠKOVI GOSPODARENJA ŠUMSKIM RESURSIMA U FEDERACIJI BIH I UPRAVLJANJE TROŠKOVIMA
}

\section{Forest management costs in the Federation of $B \& H$ and cost management}

\author{
Sabina Delić ${ }^{1}$, Mersudin Avdibegović ${ }^{1}$, Dženan Bećirović ${ }^{1}$, Bruno Marić1 ${ }^{1}$ \\ Senka Mutabdžija ${ }^{1}$, Amila Brajić ${ }^{1}$, Emsad Pružan $^{2}$
}

\begin{abstract}
This paper deals with the forestry production cost analyses realised in Federation of B\&H. The results of research point out on high differences of production costs between individual forest enterprises, caused by various ways of cost calculation, as well as by various production conditions. Therefore, the data obtained from enterprises are not comparable in whole, and as such, the data could not be used as the bases for calculation of an objective forestry production cost.

To effect the activity based costing (e.g. activity of silviculture or forest utilization) is of particular importance. The used methodology is based on traditional costing, which is appropriate only for calculating direct costs, and not adequate to determine overhead (indirect) costs. Regarding these costing methods for calculating costs in forest enterprises, their performed forest activities are not appropriately valued. Today, as overhead costs are of considerable importance, the demand for more accurate costing methods has increased in the field of forest management. ABC (Activity Based Costing) method is a new dimension of cost analysis to record costs for each forest activities, towards objective forest management cost production determined. At the same time, it reveals the necessary costs for each activity, assures the proper layout of overhead costs to the forest activities.

On the base of the defined forest activities for realization of forest management goals, as well as forest production capacities, we could understand the forest enterprises ability to achieve the goals and also to pay rent for using forest resources.
\end{abstract}

Key words: unit cost, cost of production, direct and overhead cost, Activity Based Costing (ABC), production ability, rent.

\footnotetext{
${ }^{1}$ Šumarski fakultet Univerziteta u Sarajevu - Forestry Faculty, University of Sarajevo

${ }^{2}$ Kantonalna Uprava SBK -
} 


\section{Izvod}

U radu je izvršena analiza troškova proizvodnje šumarstva na području Federacije $\mathrm{BiH}$. Rezultati istraživanja ukazuju na visok stepen variranja strukture cijene proizvodnje između preduzeća šumarstva, što je posljedica načina kalkulisanja troškova, ali i različitih uslova privređivanja. Zbog toga dobiveni podaci iz preduzeća nisu u potpunosti komparabilni i ne mogu biti pouzdan osnov za izračunavanje objektivne cijene proizvodnje u šumarstvu.

U cilju korektnog utvrđivanja cijene proizvodnje proizvoda šumarstva bitan je obračun troškova po djelatnostima (npr. djelatnosti uzgajanja i iskorištavanja šuma). Tradicionalni metod evidencije i praćenja troškova se ne zasniva na alokaciji troškova po djelatnostima i adekvatan je za kalkulaciju direktnih troškova, dok nije prilagođen determinisanju i pravilnom rasporedu indirektnih troškova. Indirektni troškovi $u$ šumarstvu su danas izuzetno visoki, što uslovljava potrebu za preciznijim metodama određivanja cijene proizvodnje. ABC (Activity Based Costing) predstavlja novi pristup u analizi troškova. Primjenom ABC sistema, koji podrazumijeva praćenje troškova za svaku aktivnost, osigurao bi se pravilan raspored indirektnih troškova po pojedinim aktivnostima u cilju utvrđivanja realne cijene proizvodnje. Istovremeno bi bila omogućena identifikacija nepotrebno nastalih troškova.

Sagledavanjem ukupnih obaveza preduzeća šumarstva za ostvarenje ciljeva gospodarenja s jedne strane, i proizvodnih mogućnosti šume s druge strane, mogle bi se utvrditi objektivne sposobnosti preduzeća za njihovo izvršenje, ali takođe i za plaćanje obaveza državi (rente) po osnovu korištenja šumskih resursa.

Ključne riječi: cijena koštanja, cijena proizvodnje, direktni i indirektni troškovi, alokacija troškova po djelatnostima, proizvodne mogućnosti, renta.

\section{Uvod - Introduction}

Djelatnost šumarstva je jedinstven proces povezanih djelatnosti uzgajanja, zaštite i iskorištavanja šuma. Iskorištavanje šuma u šumarskoj ekonomskoj literaturi nije nikada pružalo toliko teoretski zamršenog materijala kao što je to uzgajanje šuma (FIGURIĆ, 1996). Proces proizvodnje u iskorištavanju šuma koji se realizuje u relativno kratkim periodima, uz normalni stalni i obrtni kapital, odvija se po zakonu prosječne profitne stope. U takvim uslovima je omogućena primjena svih ekonomskih kategorija gdje svi ekonomski principi mogu doći do punog izražaja, bez obzira na prirodne i druge faktore privređivanja.

Za razliku od iskorištavanja šuma, specifične karakteristike uzgojnog šumarstva čine ovu djelatnost bitno različitom od svih drugih privrednih grana. U nastojanju da se nađe veza i određeni odnosi između sredstava koja se ulažu postepeno stotinama godina i konačnih prihoda, morali su se pojaviti teoretski i praktični problemi. Pri tome se nije mogla tačno definisati ni uloga drvne zalihe koja ima neke karakteristike stalnog, ali i obrtnog kapitala. Uloženi kapital i profit koji se stvara na osnovu 
ulaganja ima veoma spor obrt. Zbog toga se postavlja pitanje racionalnosti ulaganja $u$ ovu proizvodnju. S obzirom da proces proizvodnje u šumarstvu premašuje ljudski vijek, odnos čovjeka prema ovom resursu se veoma često zasnivao na politici ostvarenja kratkoročnih ekonomskih interesa u vidu ostvarenja što veće korisi iz šume. Posljedice takvog djelovanja se ogledaju $u$ devastiranim i uništenim ogromnim površinama šuma kod nas i u svijetu. Iako cijene šumskih drvnih sortimenata imaju rastući trend, ostvareni prihodi u proizvodnji drveta su manji od prihoda $u$ djelatnostima sa kraćim ciklusom obrta. Zato je sa aspekta interesa vlasnika kapitala, ulaganje u ovu djelatnost neinteresantno, a preduzeća šumarstva nisu ničim stimulisana za ulaganje $u$ dugoročne investicije, te se $u$ mnogim slučajevima izvršavaju samo obaveze koje nameće Zakon. Zbog toga bi bilo opravdano razmišljanje o " ... stimulaciji preduzeća koja finansiraju nove investicije u biološke radove od strane države po utvrđenim kriterijima " (KRALJIĆ, 1982).

$\mathrm{U}$ našim uslovima je privređivanje $\mathrm{u}$ šumarstvu zasnovano na integralnom principu, što je jedino i opravdano. Međutim, mora se naglasiti neophodnost ekonomske valorizacije biološke reprodukcije koja se ogleda kroz objektivnost utvrđivanja cijene koštanja, vrijednosti proizvodnje i tržišne vrijednosti. To znači da je potrebno utvrđivanje pune vrijednosti bioloških radova u kojoj su sadržani svi troškovi stalnog i opticajnog kapitala, profit koji se ostvaruje u tim proizvodnjama, porezi, doprinosi i ostale obaveze.

Ovo je važno istaći zato što $u$ šumarstvu ne postoji jedinstven način utvrđivanja troškova i vrijednosti bioloških radova, tako da se i pri ujednačenim uslovima privređivanja te vrijednosti razlikuju. U većini slučajeva te vrijednosti su niže od realnih iznosa, što se u konačnom negativno odražava na iskalkulisanu cijenu šumskih drvnih sortimenata.

Negativne posljedice djelovanja takvih mjera se ogledaju preko stanja šumskog fonda i cjelokupnog privređivanja u šumarstvu. Zakonski propisi moraju biti takvi da se može osigurati prosta reprodukcija, odnosno integritet šumskih sastojina.

Pitanje finansiranja proširene reprodukcije ne treba da bude samo obaveza preduzeća šumarstva, već je neophodno uključivanje cjelokupne društvene zajednice kao korisnika ovog dobra od opšteg interesa.

\section{CILJEVI I PODRUČJE ISTRAŽIVANJA - The objectives and the research area}

Osnovni cilj ovih istraživanja je analiza troškova preduzeća šumarstva prilikom gospodarenja šumskim resursima kako bi se odredila objektivna cijena proizvodnje šumarstva Federacije BiH. To može poslužiti kao osnova za ocjenu mogućnosti pojedinih preduzeća za realizaciju potrebnih investicija u šumsko-biološku reprodukciju, ali takođe i kao osnov za određivanje dijela nadoknade vlasniku šuma za njihovo korištenje.

Pored toga, cilj je bio da se ukaže na važnost upravljanja i praćenja troškova uz primjenu savremenih metoda upravljanja troškovima, navodeći prednosti $\mathrm{ABC}$ metoda (Activity Based Costing) i mogućnost njegove primjene u šumarstvu. 
Analiza je bazirana na zvaničnim podacima iz 2006. godine za preduzeća šumarstva koja egzistiraju na području Federacije. Istraživanjem su obuhvaćena sva kantonalna šumskogospodarska preduzeća (ŠGP): "Unsko-sanske šume", " Šume Tuzlanskog kantona", ŠGP "Zeničko-dobojskog kantona", "Bosansko-podrinjske šume", "Srednjobosanske šume", ŠGD Ž ZH d.o.o. Posušje, "Sarajevo šume", "Hercegbosanske šume" i 4 preduzeća u Hercegovačko-neretvanskom kantonu (Šumarstvo "Prenj", Šumarstvo "Ljuta", Šumarstvo "Srednjeneretvansko" i "Šume Herceg-Bosne" HB), koja su organizacijski samostalna.

\section{METODE RADA - The Methods}

S obzirom na karakter istraživanja, u procesu prikupljanja podataka, analize i interpretacije rezultata korištene su adekvatne naučno-istraživačke metode. Metod analize i sinteze je korišten pri prikupljanju, obradi i prezentaciji kvantitativnih pokazatelja poslovanja svih preduzeća u Federaciji $\mathrm{BiH}$, te istraživanju literarnih izvora. Metod komparacije je korišten u poređenju dobivenih pokazatelja poslovanja analiziranih preduzeća, kao i u poređenju rezultata rada sa drugim autorima, dok je u definisanju određenih prijedloga za otklanjanje uočenih nedostataka u preduzećima po analiziranoj problematici korišten normativni metod.

Pri obradi prikupljenih podataka korišteni su standardni statistički obračuni, od kojih prvenstveno metod relativnih (procentualnih) odnosa.

\section{REZULTATI ISTRAŽIVAnja - The results of the study}

\section{Cijena koštanja i cijena proizvodnje drvnih sortimenata}

Cijena koštanja predstavlja ukupno utrošeni kapital u proizvodnji, tj. individualno različite utroške pojedinih kapitala u preduzećima šumarstva. Analizom je utvrđeno da su ukupni troškovi gospodarenja šumskim resursima u šumarstvu Federacije BiH u analiziranoj godini iznosili 179,67 miliona KM ili 81,04 KM/m $\mathrm{m}^{3}$ neto proizvedenih sortimenata. U strukturi cijene koštanja troškovi radne snage su zastupljeni sa $39,01 \%$, amortizacija je 4,67\%, materijalni troškovi učestvuju sa $10,17 \%$, dok usluge i ostali troškovi čine $46,15 \%$ ukupne cijene koštanja. Uočava se visok procenat posljednje stavke u strukturi troškova što se može objasniti visokim udjelom troškova usluga trećih lica na ime izvođenja usluga iskorištavanja šuma. Struktura cijene koštanja odstupa od prosječne strukture i jako varira po pojedinim preduzećima. To je posljedica različitih materijalno-tehničkih i ljudskih resursa pojedinih preduzeća (DELIĆ, 2009).

Vrijednost ostvarene proizvodnje u šumarstvu se utvrđuje na osnovu utrošenih sredstava, tj. cijene koštanja i nove vrijednosti koja je nastala u proizvodnji (dobiti, profita). U analiziranoj godini ukupna vrijednost proizvodnje u šumarstvu Federacije 
BiH iznosi 182,4 miliona KM (prihodi od drveta i ostali prihodi). Prosječna vrijednost proizvodnje $1 \mathrm{~m}^{3}$ drvnih sortimenata je $82,25 \mathrm{KM}^{3}$

$\mathrm{Na}$ grafikonu 1. je prikazana struktura cijene proizvodnje u šumarstvu Federacije $\mathrm{BiH}$, gdje je udio troškova radne snage 31,61\%, amortizacije 3,78\%, materijalnih troškova $8,24 \%$, dok su ostali troškovi i usluge (sječe i izrade) zastupljeni sa $37,37 \%$. Prosječno ostvarena dobit po jedinici neto proizvedene prosječne drvne mase je iznosila $1,25 \mathrm{KM} / \mathrm{m}^{3}$.

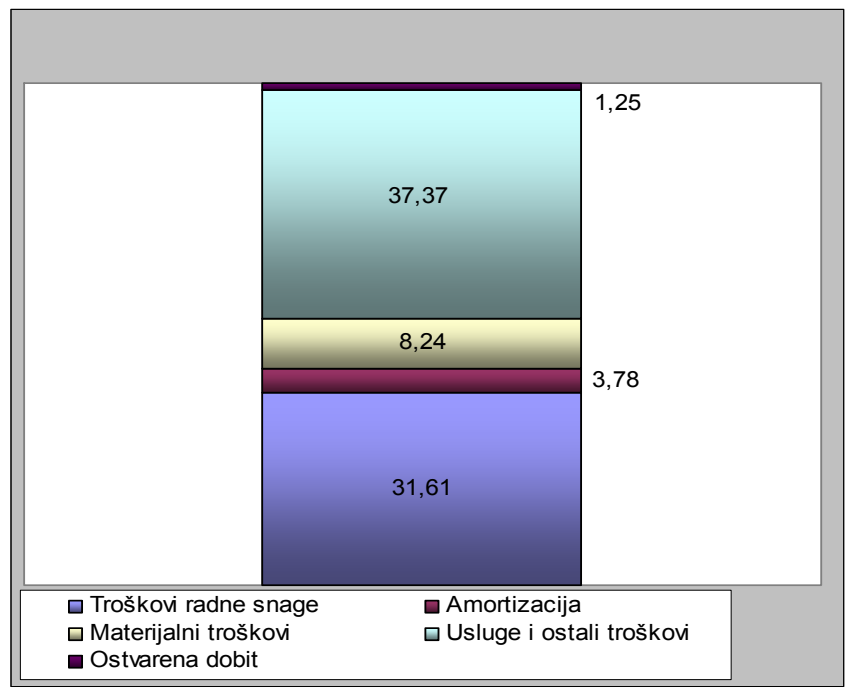

Grafikon 1. Struktura prosječne cijene proizvodnje u šumarstvu $\mathrm{FBiH}\left(\mathrm{KM} / \mathrm{m}^{3}\right)$ Graph 1. Average production cost structure in forestry of Federation $B \& H\left(\mathrm{KM} / \mathrm{m}^{3}\right)$

Cijena proizvodnje po pojedinim preduzećima je prikazana na grafikonu 2, gdje se uočava širok dijapazon variranja. Najnižu cijenu proizvodnje su ostvarile "Bosansko-podrinjske šume" u iznosu od $41,21 \mathrm{KM} / \mathrm{m}^{3}$, a najveću Šumarstvo "Ljuta" i "Sarajevo šume" (oko $140 \mathrm{KM} / \mathrm{m}^{3}$ ). Pored veličine, analizom je utvrđena i različita struktura cijene proizvodnje po preduzećima.

Dobit po $\mathrm{m}^{3}$ neto sortimenata iznosi od 0,08 KM (Bosansko-podrinjske šume) do $10,43 \mathrm{KM} / \mathrm{m}^{3}$ (Šumarstvo „Ljuta“). Šumarstvo „Prenj“ Konjic je imalo gubitak od $13,88 \mathrm{KM} / \mathrm{m}^{3}$ a "Šume Herceg-Bosne" $58,25 \mathrm{KM} / \mathrm{m}^{3}$. Razlike u ostvarenoj dobiti su posljedica različitih prirodnih uslova u kojima se odvija proizvodnja i raspoloživih materijalno-ljudskih resursa. Tu se posebno ističu sastojinske prilike, orografski uslovi, pristupačnost terena, otvorenost područja, različita udaljenost od tržišta i dr. Po

3 Pri utvrđivanju vrijednosti proizvodnje korektno bi bilo rasporediti ukupnu ostvarenu vrijednost u proizvodnji drvne mase. To znači da bi trebalo poznavati ukupan prihod od realizacije drvnih sortimenata (što je poznato u preduzećima), ali i troškove koji su izazvani tom proizvodnjom. Međutim, u preduzećima je, prema sadašnjem načinu evidentiranja troškova, teško izračunati tačan iznos tih troškova, pa su i dobijene vrijednosti približne. 
tom osnovu, preduzeća koja imaju niže cijene koštanja od prosječnih ostvaruju i ekstraprofit koji je rezultat prirodnih pogodnosti, povoljnijeg položaja i nižih transportnih troškova. Taj ekstraprofit se ispoljava $u$ obliku diferencijalne rente položaja. Pored ovog oblika javlja se i diferencijalna renta plodnosti kao posljedica boljih boniteta staništa i boljeg stanja šumskog fonda.

To upućuje na zaključak da cijena proizvodnje zavisi od uslova privređivanja i da se na osnovu toga stiču različite mogućnosti ostvarenja prihoda ali i različitih potreba za ulaganjem. Preduzeća koja gospodare ekonomski dobrim šumama realizuju značajne prihode po osnovu realizacije drvnih proizvoda. Istovremeno po pravilu je $u$ takvim područjima manje izražena potreba za ulaganjima u pošumljavanje i ostale šumsko-uzgojne radove jer je prirodno podmlađivanje izuzetno dobro.

S druge strane, šumarska preduzeća koja gospodare lošijim šumama imaju veću potrebu za investiranjem u biološku reprodukciju a manje ekonomsko-finansijske mogućnosti za njihovu realizaciju. Dakle, ovdje u potpunosti dolaze do izražaja različiti uslovi privređivanja koje je potrebno uvažavati pri rješavanju pitanja finansiranja biološke reprodukcije.

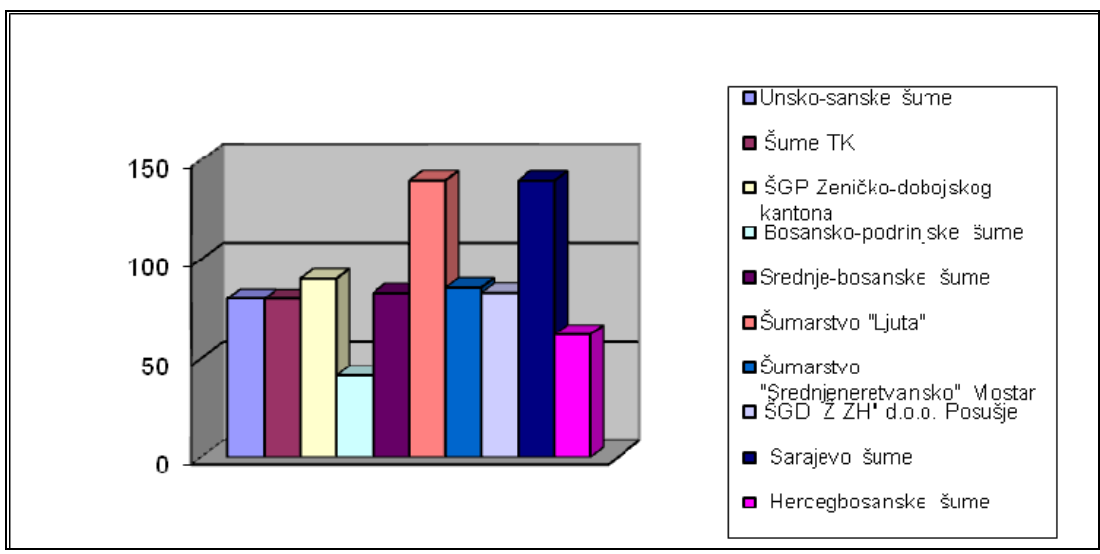

Grafikon 2. Prosječna cijena proizvodnje $\mathrm{m}^{3}$ po preduzećima šumarstva $\mathrm{FBiH}\left(\mathrm{KM} / \mathrm{m}^{3}\right)$ Graph 2 Average production cost per $\mathrm{m}^{3}$ of the different forest enterprises in Federation of $B \& H\left(K M / m^{3}\right)$

\section{DISKUSIJA - Discussion}

\section{Teoretsko pojašnjenje strukture tržišne cijene proizvoda šumarstva}

Tržišna cijena proizvoda šumarstva bi prema radnoj teoriji vrijednosti trebala imati sljedeću strukturu:

- cijena proizvodnje iskorištavanja šuma (ukupna cijena koštanja svih faza sječe i izrade te izvlačenja šumskih drvnih sortimenata do šumskog kamionskog puta uvećana za profit koji se stvara u ovoj fazi); 


\section{Sabina Delić, Mersudin Avdibegović, Dženan Bećirović, Bruno Marić, Senka Mutabdžija, Amila Brajić, Emsad Pružan}

- cijena biološke reprodukcije (puna cijena koštanja svih radova uzgajanja, zaštite, izgradnje šumskih saobraćajnica uvećana za profit koji se stvara u ovoj fazi);

- rentovni elementi (diferencijalna renta I - plodnosti i položaja, monopolska renta i apsolutna renta - nadoknada vlasniku).

Na shemi 1. je prikazana struktura tržišne cijene proizvoda šumarstva na bazi teorije vrijednosti (ŠAKOvIĆ, 1980).

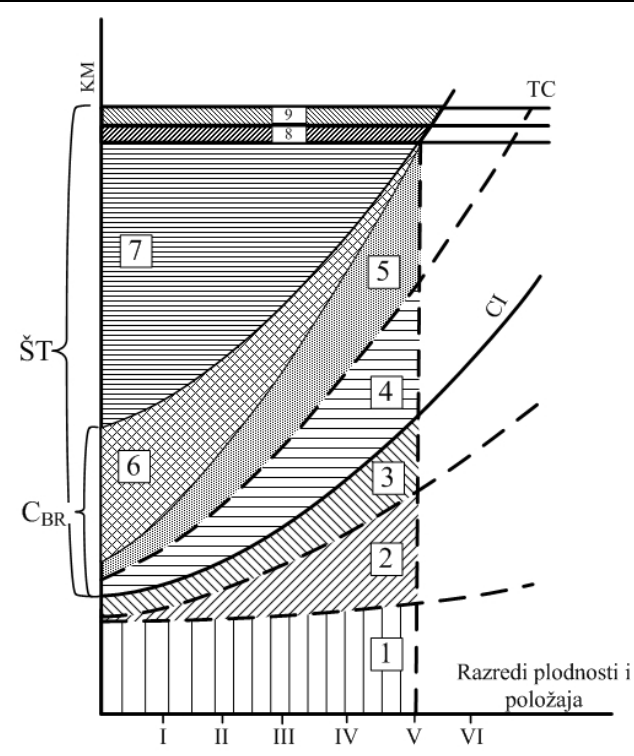

Legenda:

TC - tržišna cijena šumskog drvnog sortimenta

1- puna cijena koštanja sječe i izrade proizvoda

2- puna cijena koštanja ukupnog šumskog transporta

3- profit koji se formira u iskorištavanju šuma

Ci- cijena proizvodnje iskorištavanja šuma $(1+2+3)$

4- puna cijena koštanja biološke reprodukcije

5- profit koji se formira u biološkoj reprodukciji

6- diferencijalna šumska renta plodnosti (diferencijalna renta I)

7- diferencijalna šumska renta položaja (diferencijalna renta I)

8- apsolutna renta

9- monopolska renta

Cbr- cijena biološke reprodukcije $(4+5)$

ŠT- šumska taksa

Shema 1. Struktura tržišne cijene proizvoda šumarstva (prema ŠAKOVIĆU, 1980.)

Shema 1 The market price structure of forestry products (according ŠAKOVIĆ, 1980.) 
Iz ovog teoretskog objašnjenja slijedi potreba poznavanja cijene proizvodnje za djelatnost uzgajanja $i$ iskorištavanja šuma. $U$ sadašnjim uslovima proizvodnje $u$ šumarstvu Federacije BiH je, zbog načina evidentiranja troškova i računovodstvenih obračuna koji se iskazuju zajedno za obje (sve) djelatnosti, veoma teško izračunati cijenu proizvodnje po djelatnostima. Raspoređivanje nastalih troškova (alokacija) je otežano, naročito kod općih (indirektnih) troškova.

Istraživanja pokazuju da je zastupljenost troškova koji imaju karakter općih troškova u preduzećima šumarstva i do $40 \%$ (DELIĆ, 2006). Raspodjela ovih troškova na djelatnosti uzgajanja šuma i iskorištavanja šuma bi se mogla izvršiti primjenom različitih kalkulativnih metoda koristeći adekvatne ključeve za raspodjelu (npr. preko stope općih troškova gdje se kao ključ za raspodjelu koriste pojedine vrste direktnih troškova). Koristeći ovu metodiku, ranija istraživanja pokazuju da od ukupnih troškova preduzeća šumarstva, na troškove djelatnosti uzgajanja šuma otpada oko 48 $\%$, a oko $52 \%$ na djelatnost iskorištavanja šuma (DELIĆ, 2006). Kada su u pitanju opći troškovi, njihov veći dio pripada djelatnosti uzgajanja šuma. Prema istim istraživanjima odnos direktnih i općih troškova u djelatnosti uzgajanja šuma je $58: 42$, dok je u iskorištavanju šuma odnos $74: 26$.

Adekvatna alokacija troškova bi bila od izuzetne važnosti u cilju mogućnosti identifikacije nepotrebnih troškova i njihovog otklanjanja. S druge strane, poznavanje općih troškova je važno u cilju utvrđivanja objektivne cijene koštanja, naročito biološke reprodukcije. Na taj način bi se mogao objektivnije utvrditi potreban iznos sredstava za jednostavnu biološku reprodukciju i utvrditi da li je Zakonom propisani iznos adekvatan ili ne.

Jedan od načina poboljšanja ovakvih obračuna je zasnovan na obračunu troškova po aktivnostima ili tzv. Activity Based Costing (ABC).

\section{Metode upravljanja troškovima}

Upravljanje troškovima (Cost Management) je poseban način upravljanja preduzećem i vođenja poslovanja pri čemu se najveća pažnja posvećuje optimalizaciji troškova. Da bi ostvarilo svoje ciljeve poslovanja, preduzeće treba nadjačati konkurenciju, ne samo danas već i u budućnosti, a pomoću upravljanja troškovima ono to može učiniti efikasnijim korištenjem internih resursa preduzeća i strogom kontrolom troškova. Upravljanje troškovima se definiše kao filozofija, stav (misija) i niz tehnika kojima je cilj kreiranje veće vrijednosti uz niže troškove (MIKIĆ, 2009).

Poznavanje ponašanja troškova u sadašnjosti i budućnosti preduzeća je bitan faktor $\mathrm{u}$ određivanju cijene proizvodnje, profitabilnosti i kreiranju strategije preduzeća. Značaj upravljanja troškovima potvrđuju istraživanja provedena na više od dvije hiljade američkih preduzeća, pri čemu su uštede u ukupnim troškovima od prosječno $1 \%$ rezultirale povećanjem operativne dobiti od 10,1\% (BožıČEVIĆ, 2009). Nije teško izračunati šta bi značila redukcija troškova proizvodnje šumarstva Federacije $\mathrm{BiH}$ od samo $1 \%$. U svijetu se danas koriste različiti modeli i metode upravljanja troškovima, a neki od njih su: 
- Model tradicionalnog upravljanja proizvodnim troškovima (Traditional Product Costing),

- Model upravljanja troškovima baziran na procesima (Process Based Costing),

- Model upravljanja troškovima na bazi aktivnosti (Activity Based Costing $A B C$,

- Model ciljnih troškova (Target Costing),

- "Kaizen" (Kaizen Costing),

- Analiza vrijednosti (Value Engineering),

- Model upravljanja troškovima kvaliteta (Quality Cost Management).

Navedeni modeli nisu isključivi i svaki od njih se može koristiti za upravljanje troškovima, a u praksi se koriste kombinacije različitih modela.

Tradicionalni sistem obračuna troškova u našoj praksi se zasniva na obračunu direktnih i općih troškova u ukupnom iznosu, pri čemu dolazi do problema adekvatne raspodjele općih troškova na nosioce (proizvode, usluge) u cilju obračuna cijene koštanja. Iz toga proizlaze nerealne i netačne kalkulacije na osnovu kojih bi se mogle donositi odgovarajuće odluke. Tradicionalni model ima svoje nedostatke koji se ogledaju u ograničenoj upotrebljivosti za donošenje odluka i nedovoljnom uvažavanju tržišta. Ovaj model ne daje odgovore na pitanja kao što su: kako riješiti problem (da li otkazi, smjena rukovodstva, prekid projekta ili sve po malo), gdje praviti rezove, kako je to najlakše otkriti, kako promijeniti poslovne procese i slično. S obzirom na prisustvo visokog procenta općih troškova u šumarstvu, nameće se potreba za preciznijim informacijama o nosiocima i uzrocima troškova te njihovim međusobnim odnosima i vezama. "Ako računanju troškova pristupimo nakon njihovog nastanka, više nemamo mogućnost da iste smanjimo" (KAVČlć,1997).

Kao i kod provođenja drugih strategija poslovanja, uvođenje sistema upravljanja troškovima zahtijeva potpunu posvećenost preduzeća od menadžmenta do uključenosti zaposlenika na svim hijerarhijskim nivoima i uvođenje sistema kontrole efikasnosti i unapređenja aktivnosti koje će rezultirati stvaranjem uvećane vrijednosti, a eliminisati one aktivnosti koje tome ne doprinose (MIKIĆ, 2009).

\section{ABC (Activity Based Costing) metoda obračuna troškova}

$\mathrm{ABC}$ metoda je metoda praćenja i upravljanja troškovima. Ona predstavlja novu dimenziju u analizi troškova koja je prvi put prezentirana 1987. godine na Harvardu (KAVČlć, 1997). Obračun troškova se zasniva na aktivnostima kao osnovnim nosiocima troškova. ABC daje bolje informacije od tradicionalnog sistema obračuna jer pokazuje nosioce, uzroke troškova i veze i odnose između njih. Na ovaj način se dolazi do informacija kako troškovi jednog zadatka utiču na efikasnost obavljanja drugog zadatka, u kakvom su odnosu troškovi jednog procesa sa troškovima drugog procesa $\mathrm{u}$ okviru jedne određene aktivnosti, te mogućnost identifikacije glavnih uzroka (izvora) troškova svih procesa. Sve ovo utiče na mogućnost povećanja efikasnosti i efektivnosti operacija. 
Primjena $\mathrm{ABC}$ metode zahtijeva izradu adekvatne metodologije i odgovarajuće pripremne aktivnosti koje se ogledaju u sljedećem:

- projektovanje ABC sistema (definisanje svrhe i područja primjene, prilagođavanje informacionog sistema za zadovoljenje postavljenih ciljeva, kreiranje benchmarking analize, obezbjeđenje timskog rada i povezivanje različitih funkcionalnih jedinica organizacije);

- definisanje ključnih tačaka mjerenja (identifikacija nosioca troškova);

- popis mogućih problema koji se mogu javiti, kako ne bi umanjili efikasnost ovog modela (pogrešna ili nepotpuna identifikacija aktivnosti, nedostatak pravovremene analize, pogrešan ili netačan benchmarking sa liderima u struci, nepouzdani i nekompletni podaci).

Prednosti ABC sistema se ogledaju u sljedećem:

- jasno definisanje procesa, identifikacija uzroka nastanka troškova, svođenje troškova po jedinici, dobivanje korektnih izvještaja;

- dobivanje korisnih informacija o tome kako je novac utrošen i kako komparacijom sa drugima (benchmarking) unaprijediti kvalitet;

- minimiziranje mogućnosti stvaranja iskrivljene slike o troškovima, kao posljedice proizvoljne alokacije indirektnih troškova.

\section{Mogućnost primjene $\mathrm{ABC}$ costinga u šumarstvu}

Kao što smo prethodno istakli, u šumarstvu egzistiraju bar dvije djelatnosti (uzgajanje i iskorištavanje šuma), a u okviru svake djelatnosti se odvija niz aktivnosti. ABC metoda je najprikladnija u procesu određivanja uzroka troškova šumskog gospodarenja. To ukazuje na neophodne troškove za svaku aktivnost i daje odgovor na pitanje zašto su troškovi nastali. Na taj način se usmjerava puna pažnja menadžmenta na ukupne troškove. Determinišući stvarne troškove dolazi se do identifikacije mogućnosti za unapređenje produktivnosti rada i ukupne efikasnosti poslovnih procesa.

U Sloveniji je vršeno istraživanje pri čemu su primjenom $A B C$ metoda identifikovani i analizirani indirektni (opći) troškovi. Analizirana je faza iskorištavanja šuma (aktivnosti sječe, izrade i izvoza) i definisani su uticajni faktori na nastanak troškova. Nakon toga su analizirani odnosi između troškova i uzroka koji dovode do njihovog nastanka (varijabli). Razvijen je matematički model zasnovan na regresionoj analizi koji je testiran na 10 preduzeća koja su izabrana slučajnim izborom. Komparacijom trenutnih troškova po tradicionalnom načinu obračuna i troškova koji su izazvani neophodnim aktivnostima definisanim kroz ABC sistem i matematički model zaključeno je da su sadašnji indirektni troškovi daleko veći. Bez aplikacije ABC procedure nepotrebni indirektni troškovi ne bi bili identifikovani (KAVČıć, 1997). Autori zaključuju da je praktična primjena $\mathrm{ABC}$ sistema moguća i prihvatljiva $u$ šumarstvu. 


\section{ZAKLJUČCI - Conclusions}

Analiza troškova gospodarenja šumskim resursima u Federaciji BiH je pokazala da su ukupni troškovi u analiziranoj godini iznosili 179,67 miliona KM ili 81,04 $\mathrm{KM} / \mathrm{m}^{3}$ neto proizvedenih sortimenata. Struktura cijene koštanja je različita po pojedinim preduzećima kao posljedica, prije svega različitih uslova privređivanja, ali i različite metodologije obračuna troškova pojedinih aktivnosti. Iz ovog proizlazi jasna potreba za izradom jedinstvene metodike kalkulacija troškova svih aktivnosti $u$ preduzećima šumarstva.

Vrijednost ostvarene proizvodnje u šumarstvu Federacije BiH je iznosila 182,4 miliona KM ili $82,25 \mathrm{KM}$ po $\mathrm{m}^{3}$ neto drvnih sortimenata. Dakle, prosječna dobit na nivou šumarstva Federacije BiH iznosi 1,25 KM, a njen iznos varira od 0,08 do 10,43 KM za pojedina preduzeća, uz napomenu da su neka preduzeća poslovala i sa gubitkom. Jedna od mogućnosti za povećanje ukupne stvorene vrijednosti u preduzećima šumarstva jeste racionalizacija troškova.

U strukturi troškova u šumarstvu uočava se visok udio općih troškova. Proizvoljnom alokacijom tih troškova stvara se iskrivljena slika o troškovima. U cilju utvrđivanja objektivne cijene proizvodnje važno je njihovo praćenje, blagovremena identifikacija i adekvatna raspodjela na pojedine nosioce.

Preduzeća šumarstva koriste tradicionalni metod upravljanja troškovima koji ima svoje nedostatke. Oni se ogledaju u tome da ne obezbjeđuju informacije o uzrocima nastanka troškova svih procesa, uticaju troškova izazvanih jednim zadatkom na efikasnost izvršenja drugog zadatka, te informacije o odnosu troškova jednog procesa sa troškovima drugog procesa u okviru jedne određene aktivnosti.

Ti nedostaci se mogu otkloniti primjenom savremenih metoda upravljanja troškovima, a jedna od tih metoda je ABC (Activity Based Costing). Ovaj metod se sastoji u praćenju troškova po aktivnostima. Primjenom ABC metode mogu se dobiti blagovremene informacije o nosiocima i uzrocima troškova, njihovim međusobnim vezama i odnosima, što daje mogućnost za otklanjanje nepotrebnih troškova. Sve ovo utiče na moguće povećanje efikasnosti i efektivnosti operacija, jer nakon nastanka troškova nemamo više mogućnost njihovog smanjenja niti otklanjanja.

Mogućnost praktične primjene $\mathrm{ABC}$ costinga $\mathrm{u}$ šumarstvu je potvrđena istraživanjem u Sloveniji. Za primjenu $\mathrm{ABC}$ metoda potrebno je izraditi adekvatnu metodologiju i obezbijediti neophodne preduslove za njegovu primjenu.

\section{Zahvala - Acknowledgement}

Analiza troškova gospodarenja šumskim resursima je izvršena u okviru projekta „Istraživanje cijene gospodarenja šumama i šumskim resursima na području Federacije BiH" koji je finansiralo Federalno ministarstvo poljoprivrede, vodoprivrede i šumarstva u 2008. godini, na čemu im se i ovom prilikom zahvaljujemo. 


\section{LITERATURA - References}

BožIČEVIĆ, D. (2009): Upravljanje troškovima na temelju aktivnosti kao instrument ekonomike procesa, Orkis, Računovodstveno finansijski portal

Buchanan, T. (2007): Activity-Based Costing, Product/Cost Relationships, omepages.ius.edu/TABUCHAN/.../Activity\%20Based\%20Costing.doc

DELIĆ, S. (2009): Biological Reproduction in forestry in Bosnia and Herzegovina Practical issues of the forest law, Legal aspects of European forest sustainable development, Proceedings of the $10^{\text {th }}$ international IUFRO Symposium, Sarajevo

Delić, S., Avdibegović, M. (2009): Prihodi i troškovi proizvodnje u šumarstvu Federacije Bosne i Hercegovine, Radovi Šumarskog fakulteta Univerziteta u Sarajevu, Broj 2, (knjiga XL), str, 71-82, Šumarski fakultet, Sarajevo

DELIĆ, S. (2006): Istraživanje modela finansiranja biološke reprodukcije u šumarstvu Bosne i Hercegovine, Doktorska disertacija, Šumarski fakultet, Sarajevo

FIGURIĆ, M. (1996): Uvod u ekonomiku šumskih resursa, Sveučilište u Zagrebu, Šumarski fakultet, Zagreb

Granof, H. M., Platt, D.E., Vaysman, I. (2000): Using Activity-based Costing to Manage more Effectively, Department of accounting College of Business Administration University of Texas at Austin, costkiller.net/.../UsingActivity-Based-Costing-to-Manage-More-Effectively.pdf

KAVČIĆ, S., ZADNIK StIRN, L. (1997): Activity-Based Costing in Forestry, Recent Developments in Accounting and Managerial Economics for an Environmentally- Friendly forestry International Symposium, Nancy (France), pg. 84-93.

KRALJIĆ, B. (1982): Stimuliranje ulaganja u dugoročne biološke investicije u šumarstvu, Šumarski list 9-10, Godište 106, str. 359-366, Zagreb

MıKı́́, M. (2009): Upravljanje troškovima u malim i srednjim proizvodnim poduzećima, Zbornik Ekonomskog fakulteta u Zagrebu, Vol.7, No. 1, Zagreb, hrcak.srce.hr/file/63592

ŠAKOVIĆ, Š. (1980): Finansiranje biološke reprodukcije - cijena drveta u dubećem stanju, Skripta, Sarajevo

http://www.knowledge-banks.org/informator/koncept_mtvu.htm

http://www.kvalis.com/index.php?option=com content\&view=article\&id=303:abc-1upravljanje-trokovima-na-temelju-aktivnosti-kao-instrument-ekonomikeprocesa-\&catid=135:pm-upravljanje-procesima-i-projektima\&Itemid $=576$ 


\section{SUMMARY}

The results of this analysis show that the average costs of managing forest resources in Federation of $\mathrm{B} \& \mathrm{H}$ are $81,04 \mathrm{KM}$ per $\mathrm{m}^{3}$, while the average cost of production is also $82,25 \mathrm{KM}$ per $\mathrm{m}^{3}$ of wood assortments. Therefore, the average profit in Federation of $\mathrm{B} \& \mathrm{H}$ is $1,25 \mathrm{KM}$, and its amount varies from $0,08 \mathrm{KM}$ to 10,43 $\mathrm{KM}$ for individual enterprises.

The structure and amount of costs varies by individual enterprises as a result of different condition of economic (different stand conditions, availability of forests and the accessibility of terrain, distance from market, etc.). Besides that, there is no unique methodology for costs calculation of all activities in forest enterprises. Partition of the costs is very high, and arbitrary allocation of these costs creates distorted pictures of these costs. In order to define the objective cost of production, their monitoring, timely identification and adequate distribution to the individual carriers is very important.

Forest enterprises use traditional costing method to manage their costs, which has deficiencies. They are reflected in the fact that they do not provide information about the causes of the costs of all processes, the effects caused by the costs of the task, on efficiency of execution of another task or information about relationship between the costs of one process and the costs of another process within particular activity.

These deficiencies can be eliminated by applying modern methods of costs management, and one of these methods is ABC (Activity Based Costing). This method consists of monitoring costs of activities. With use of $\mathrm{ABC}$ method it is possible to get timely information about carriers of costs and causes of costs, their relationship and connection which provide the ability to eliminate unnecessary costs. All this affects the possibility to improve the efficiency and effectiveness of operations, because when the costs occur, there is no possibility to reduce or eliminate them. To apply the ABC method it is necessary to develop an appropriate methodology and provide the necessary prerequisites for its application. 